\title{
EDITORIAL
}

\section{PROFESSOR EMERITUS ALBERT ADU BOAHEN}

(1932-2006)

On 24 May 2006, Professor Emeritus of History Albert Adu Boahen passed away on the evening of his 74th birthday. The first Ghanaian to receive a Ph.D. in African history from the School of Oriental and African Studies (SOAS) in I959, and the first African to chair the Department of History at the University of Ghana in I 967, Adu Boahen was without a doubt Ghana's foremost historian and a distinguished statesman. His publishing career spanned some forty years, his works ranging from standard textbooks in use in Africa and the West to major interpretations of African history such as African Perspectives on Colonialism (1987), Mfantsipim and the Making of Ghana: A Centenary History, I876-I976 (1996) and Yaa Asantewaa and the Asante-British War of I9OO-I (2003). A scholar-activist, he demonstrated a consistent opposition to dictatorial rule and military regimes that earned him stints in prison. In February I988, on the platform of the Ghana Academy of Arts and Sciences, of which he was a fellow, he delivered three lectures under the title of 'The Ghanaian Sphinx: Reflections on the Contemporary History of Ghana, I972-1987' that broke the 'Culture of Silence' of the oppressive Rawlings regime and inaugurated what has been termed the 'second independence of Ghana'. Posthumously awarded the Order of the Star of Ghana on 30 June 2006 for distinguishing himself in academia and statesmanship, Boahen was given a grand state burial in July 2006. He served on the editorial board of the Fournal of African History.

The late Professor Boahen was born to Evans Adu Amankwah and his wife, Dora Afua Kissiwa, on 24 May 1932 at Osiem in the Eastern region of Ghana. The young Boahen attended the Presbyterian/United primary school from I 938 to I942, and from 1943 continued his education at Asokore Methodist School when he relocated from Osiem to live with his maternal uncle Charles Boadu at Juaben in the Ashanti region. At Asokore, Adu distinguished himself as a brilliant student. It was not surprising that he won a scholarship to one of the leading secondary schools in Ghana, Mfantsipim, in 1947. At Mfantsipim, Boahen was drawn into nationalist politics, and he participated in a students' protest in 1948 against the detention of the 'Big Six', the nationalist leaders of the United Gold Coast Convention blamed erroneously by the colonial government for masterminding the February 1948 riots. Boahen graduated from Mfantsipim in I950, and, after an intermediate Arts programme, read history at the University of Ghana. He obtained his BA with high honours in 1956 .

After his first degree from the University of Ghana, Boahen proceeded to the UK to pursue a Ph.D. in African history at the SOAS (University of London). There he studied under Roland Oliver, a pioneering historian of Africa. On graduating with a Ph.D. in I 959, Boahen took up an appointment 
as lecturer in the Department of History at the University of Ghana, at the young age of 29 . He was promoted to associate professor in 1967 , becoming chair of the History Department from i 967 to I 975 . He was appointed full professor of history in $\mathrm{I} 97 \mathrm{I}$. He served the university in various capacities, including as dean of graduate studies from I 973 to I975, and as a member of the University Council. He was made Professor Emeritus of History in I 990.

Boahen was a prolific scholar and, as a historian in a new nation, he was called upon to write textbooks on the history of Ghana for teaching at the secondary and tertiary levels. His Topics in West Africa's History (1966) and (with J. B. Webster) West Africa since I80o: the Revolutionary Years (1967) have become staples in Africa and the West and have gone through subsequent editions. Ghana: Evolution and Change in the Nineteenth and Twentieth Centuries ( I 975) remains the textbook for the teaching of Ghanaian history in Ghana. Boahen resigned from the University of Ghana in I985, dismayed at the intervention of the ruling military Provisional National Defence Council regime in the appointment of the vice-chancellor of the University. His scholarly productivity reached new heights. African Perspectives on Colonialism ( 1987) came out based on the James S. Schouler Lectures he gave at the Johns Hopkins University in 1985. His February I988 Ghana Academy of Arts and Sciences' J. B. Danquah Memorial Lectures appeared in book form the following year. Boahen would situate his alma mater in the process of nation-building in his book on Mfantsipim and the Making of Ghana: A Centenary History, I876-I976 (I996). This book was published by Boahen's own publishing company, Sankofa.

Boahen's distinguished scholarship brought him national and international recognition. In acknowledgement of his erudition, Boahen had been made a fellow of the Ghana Academy of Arts and Sciences in 1968. He became its honorary secretary from 1983 to 1985 . Visiting professorships took him to the Australian National University in I969, Columbia University in I970, Cornell in I990, the State University of New York at Binghamton in I990-I and many other universities. Professor Boahen was appointed president and consultant for the UNESCO scientific committee that oversaw the publication of the multi-volume General History of Africa between 1983 and I 999. The seventh volume of the UNESCO series edited by Boahen, Africa under Colonial Domination I880-I935 (I985), is a major landmark in the writing of the history of colonial Africa. His book on Mfantsipim won the NOMA Award for Publishing in Africa in I997. In I 999 he was awarded the UNESCO Avicenna Silver Medal for his outstanding contribution to the General History of Africa. Boahen was a member of many learned societies, such as the Historical Society of Ghana, and the Royal African Society (UK).

Though Boahen's political life is often dated to his Danquah lectures in I988, which broke the culture of silence and propelled him to national prominence, and his flag-bearer position for the New Patriotic Party in the I 992 election, his political activism long predated these momentous events. He had campaigned actively in the r 970 s against the military regime of Acheampong, who sought to thwart popular demands for a democratically elected government through a Union Government (UNIGOV) scheme. Boahen was a founding member of the People's Movement for Freedom and Justice in I978, which opposed UNIGOV, and had been imprisoned for his 
role. As presidential candidate for the New Patriotic Party (NPP) in I 992, he lost a controversial election to Rawlings. In 1998 the professor lost his position as flag-bearer of the NPP to J. A. Kufuor, but rallied to support Kufuor in a gruelling election campaign that witnessed the triumph of the NPP and the election of Kufuor as president of Ghana in 2000. Though elected to the Council of State, ill-health prevented Boahen from taking his seat on the esteemed council, as he suffered two strokes in 2000 and $200 \mathrm{I}$. He spent the last four years of his life at 37 Military Hospital in Accra.

After Boahen's first stroke in 2000, he made arrangements for the publication of some of his finished works. In 2003 he came out with two books. The first he edited with Emmanuel Akyeampong, Ivor Wilks, Nancy Lawler and Thomas McCaskie: Asantehene Agyeman Prempeh's The History of Ashanti Kings and the Whole Country Itself (2003); the second was his monograph on Yaa Asantewaa and the Asante-British War of I900-I (2003), edited by Emmanuel Akyeampong. He did not complete the long-awaited history of Juaben for which he had collected materials for years, or his history of Ghana from the earliest times. The late Professor Boahen is survived by his wife, Mary, and five children. $\mathcal{F} A H$ extends its deepest sympathy to the family of the late Professor Boahen. 